\title{
Monilukutaito muuttaa maailmaa
}

\author{
The New London Group (NLG) syntyi kehittämään \\ lukutaidon pedagogiikkaa ja kasvatuksen ja koulutuksen \\ yhdenvertaisuutta. Manifestissaan ryhmä nosti monilukutaidon \\ käsitteen uusien lukutaitojen tutkimuksen, pedagogiikan \\ ja maailman muuttamisen ytimeen. Julkaisu on vaikuttanut \\ laajasti ja syvällisesti uusien lukutaitojen tutkimukseen.
}

SYYSKUUSSA 1994 KYMMENEN kasvatustieteen ja kielen tutkimuksen tutkijaa kokoontui New Londonin kaupunkiin New Hampshiren osavaltioon Yhdysvalloissa pohtimaan agendaansa. Siihen kuuluivat kasvatuksen ja koulutuksen tulevaisuus, tasa-arvoisuus ja erityisesti - lukemisen ja kirjoittamisen kouluopetus.

Osallistujista muodostui ryhmä, joka otti nimekseen tapaamiskaupungin mukaan The New London Group, tutummin NLG. Ryhmän vetäjinä toimivat australialaiset kasvatustieteen ja lukutaidon tutkijat Mary Kalantzis ja Bill Cope. He kutsuivat ryhmän tapaamisiin tutkijoita, joita yhdisti käsitys, että kieli ja lukutaito olivat sosiaalisia, kulttuurisia ja poliittisia (Gee 2017).

Ryhmässä ajateltiin, että perinteinen painettuihin teksteihin keskittyvä lukutaito ja sen opetus eivät enää riittäneet, kun mediateknologia välitti audiovisuaalista materiaalia kiihtyvällä tahdilla. Painettuihin teksteihin keskittyvä opetus sulkisi lisäksi pois

\section{A Pedagogy of Multiliteracies: Designing Social Futures}

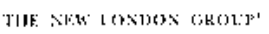

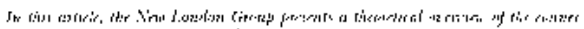

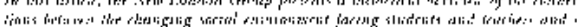

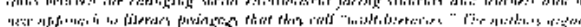

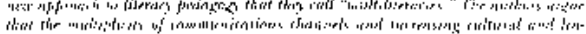

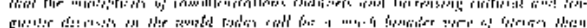

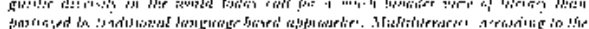

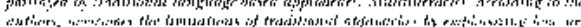

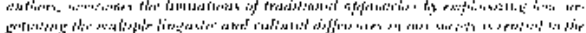

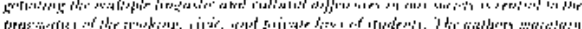

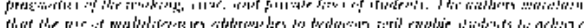
(be)

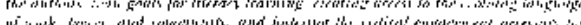

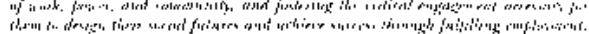

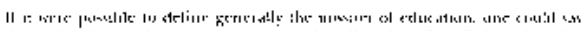

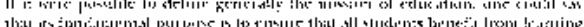

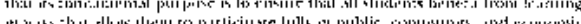
lite L Clll (1) ise

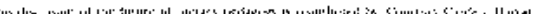

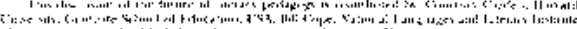

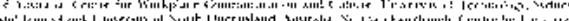

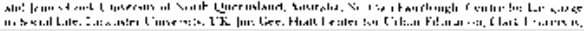


sellaisia ilmaisun ja kommunikaation muotoja, joita esimerkiksi maahanmuuttajat ja alkuperäiskansat kokivat omikseen.

Kun ensimmäisestä tapaamisesta oli kulunut pari vuotta, NLG julkaisi kasvatuksellisen manifestin $A$ Pedagogy of Multiliteracies - Designing Social Futures (NLG 1996). Se on saanut klassikon aseman niin sanottujen uusien lukutaitojen tutkimuksessa, jossa korostetaan lukutaidon sosiaalista ja kontekstuaalista luonnetta. Lukutaito on sosiaalista toimintaa, ei pelkästään yksilön kognitiivinen taito. Se on inhimillisen työn muoto, jolla on voimaa muuttaa maailmaa.

MANIFESTI TIIVISTI LUKUTAIDON monitahoisuuden yhteen käsitteeseen: monilukutaitoon (Gee 2017). Lukutaito on monessa mielessä monitahoista. Ensinnäkin jopa samassa kulttuurissa tai yhteisössä voi olla useita erilaisia tekstikäytänteitä ja lukutapahtumia. Esimerkiksi iltasadun lukemiseen ei ole yhtä kaavaa, ja se myös eroaa vaikkapa tenttikirjan lukemisesta. Toiseksi käytännöt eroavat kulttuureittain, instituutioittain ja ryhmittäin. Kolmanneksi moninaisuus tulee esiin erilaisissa tekstiyypeissä, kuten visuaalisessa, auditiivisessa tai kirjallisessa tekstissä, ja näiden yhdistelmissä sekä eri tekstilajeissa, kuten uutisessa, esseessä tai käyttöohjeessa. Neljänneksi lukutaito voidaan sisällyttää monelle alueelle, puhutaanhan muun muassa digitaalisesta, kulttuurisesta, emotionaalisesta ja tieteellisestä lukutaidosta. Lukutaidosta on moneksi, siksi NLG:n manifestissa esiintyy monikko, 'lukutaidot'.

Manifesti julkaistiin uudelleen vuonna $2000 \mathrm{Mul}$ tiliteracies - Literacy Learning and the Design of Social Futures -kirjassa (Cope \& Kalantzis 2000). Teoksesta näkee, miten eri näkökulmista ryhmäläiset katsoivat monilukutaitoa. Esimerkiksi kriittisen diskurssianalyysin uranuurtajana tunnettu Norman Fairclough lähestyi monilukutaitoa juuri diskurssiteorian näkökulmasta. Muun muassa pelillisen oppimisen teoreetikkona myöhemmin tunnetuksi tullut James Paul Gee kiinnitti puolestaan huomiota huono-osaisten oppilaiden heikkoon koulumenestykseen koska koulun tekstikäytänteet repivät heidät irti elämismaailmoistaan ja dekontekstualisoivat kielen. Kesällä 2020 edesmennyt sosiosemiotiikan tutkija Gunther Kress kirjoitti multimodaalisuudesta.
Monilukutaidon pedagogiikan tueksi NLG:n oli selvitettävä, miten kieli toimii sosiaalisena käytäntönä, miten eri taustoista tulevilla ihmisillä oli erilaisia kielenkäytön tapoja ja tekstejä - toiset kirjallisia, toiset visuaalisia - ja miten lukutaidot ja erilaisten tekstien merkityksellistämisen tavat voivat muuttaa maailmaa.

ENSIKOSKETUKSENI RYHMÄN AJATTELUUN palautuu väitöskirjaprojektiini, jossa hahmotin mediakasvatuksen etiikkaa (Kupiainen 2005). Gunther Kress oli todennut, että kuva hallitsi yhä enemmän ja enemmän kulttuuria painetun sanan sijaan, mikä muutti kommunikaation tapoja. Muutoksella oli poliittisia, taloudellisia, sosiaalisia ja kulttuurisia seurauksia (Kress 2003). Niin sanotussa totuuden jälkeisessä ajassamme visuaalinen informaatio ja sen muokkaaminen on keskeistä mediatodellisuudessa, joten Kressin sanoma on tullut ilmeiseksi. Samalla lukutaidon, ja tarkemmin vielä medialukutaidon, merkitys on korostunut. Sen voikin lukea monilukutaidon käsitteen alaan, kuten käytännössä tehdäänkin perusopetuksen opetussuunnitelman perusteissa. Niissä monilukutaito on ollut vuodesta 2014 lähtien.

Se 'monilukutaito', johon NLG viittaa manifestissaan ei kuitenkaan ole yksi yhteen suomalaisen 'monilukutaidon' kanssa. Selvää on, että perusopetuksen opetussuunnitelman perusteissa tavoite on lukutaidon ymmärtäminen aiempaa laajemmin ja tekstityypeiltään rikkaammin. Sen sijaan NLG:n korostama monilukutaitojen pedagoginen lähtökohta ja poliittisuus eivät ole siinä selvästi esillä.

NLG painotti, että yhteiskunnallinen osallisuus edellyttää lukutaitoa, joka on yksi yhteiskunnan avainteknologia. Näin on erityisesti alueilla, jotka vaativat erityisiä lukutaitoja, kuten akateeminen opiskelu ja taloudellinen ja sosiaalinen osallisuus. Monilukutaidon pedagogiikka tavoittelee oikeudenmukaisia mahdollisuuksia osallistua niihin kielenkäytön muotoihin, joita yhteiskunnassa pidetään tärkeinä, mutta samalla se laajentaa lukutaitoa alueille, jotka eivät ole kulttuurisessa keskiössä.

Omassa tutkimuksessani olen pyrkinyt yhdistämään NLG:n käsityksen lukutaidon sosiokulttuurisesta ja kontekstuaalisesta luonteesta erityisesti medialukutaitoon. Tähän sisältyy myös toimintaa erilaisten 


\section{MONILUKUTAIDON}

\section{PEDAGOGIIKKA LAAJENTAA}

\section{LUKUTAITOA ALUEILLE, JOTKA}

\section{EIVÄT OLE KULTTUURISESSA}

\section{KESKIÖSS $\ddot{A}$.}

tekstien kanssa erilaisissa konteksteissa. Olen ollut kiinnostunut muun muassa siitä, millaisia tekstejä ja teksteihin liittyviä sosiaalisia käytänteitä oppilaat tuovat kouluihin ja miten opettajat niihin suhtautuvat (Kupiainen 2013). Tutkimukseni huomioi, että oppilaat kyllä tuovat kouluihin tekstejä, mediaa ja käytänteitä omista elämismaailmoistaan, mutta ne jäävät usein opetuksessa tunnistamatta ja hyödyntämättä.

SUOMALAISEN KOULUN TODELLISUUS ei kuitenkaan ole yhtä lohdutonta kuin NLG antoi ymmärtää australialaisesta koulusta. Ryhmän jäsenistä muun muassa Mary Kalantzis ja Bill Cope työskentelivät Australiassa. He näkivät, että koululla oli siellä tendenssi sulkea pois maahanmuuttajien, alkuperäiskansoihin kuuluvien ja työväentaustaisten lasten elämismaailma, kokemus ja yhteisöt: "Koulu oli yksioikoisten oikein ja väärin vastausten, auktoritatiivisten tekstien ja autoritaaristen opettajien universumi" (Cope \& Kalatzis 2009, 168-169).

NLG etsi käsitteistöä, joka avaisi koulun ja lukemisen opettamisen tekstien ja oppilaiden moninaisuuksille niin, että oppilaat voisivat osallistua manifestin alaotsikossa mainitun yhteiskunnallisen tulevaisuuden muotoiluun. Sillä NLG tarkoitti kykyä kuvitella toisenlainen maailma.

"Kouluopetuksessa ei voida tehdä maailmaa uudelleen, mutta me voimme toteuttaa pedagogiikan avulla vision, joka luo mikrokosmoksessa transformoidun joukon suhteita ja mahdollisuuksia yhteiskunnallisia tulevaisuuksia varten, vision, joka on eletty koulussa." (NLG 1996, 72)

Monilukutaidon pedagogiikka pyrki tukemaan moninaisia tulevaisuuksia, sosiaalista diversiteettiä, moniulotteista kansalaisuutta ja moninaisia elämismaailmoja, sanalla sanoen "moneuden epistemologiaa"
(NLG 1996, 72). Se takaisi yhä useammalle pääsyn yhteiskunnalliseen osallisuuteen ilman tarvetta luopua omasta identiteettistä ja subjektiviteetista.

Koen jakavani ryhmän tavoitteen kasvatuksen ja lukutaidon maailmaa muuttavasta mahdollisuudesta. Yhteistä kontaktipintaa on erityisesti siinä, että lukutaidon - myös medialukutaidon - tavoite on luoda tiloja, välineitä ja taitoja, joilla oma ääni saadaan esiin ja kuuluviin yhteiskunnan eri tasoilla, niin lokaalisti kuin globaalistikin. Myös NLG näki mediakulttuurin mahdollisuudet muutosvoimana. Monilukutaitojen manifestin julkaisemisen aikaan elettiin optimistista "historian lopun" aikaa. Ryhmän jäsen Allan Luke esitti vuonna 2017, että ryhmässä ajateltiin "tiedon valtatien" järjestävän uudelleen aikaa, paikkaa, työtä ja identiteettejä niin, että monikulttuurisuudesta ja monikielisyydestä tulisi tuotannollisia vahvuuksia (Garcia, Luke \& Seglem 2018).

LUKUTAIDOSSA OLI NÄHTÄVISSÄ KÄÄNNE, jossa lukutaito avautui yhdenmukaisesta ja individuaalista, usein painettuun tekstiin keskittyvästä kognitiivisesta toiminnasta kohti laajempaa visuaalista, auditiivista ja kirjoitettua tekstiä yhdistävää yhteistoiminnallista muotoa. Kirjoitin itsekin optimismista innostuneena yhteistoiminnallisesta lukutaidosta (Kupiainen 2006).

"Lukutaitokäänne" tarkoitti samalla yhteiskunnallisen osallisuuden lisääntymistä. Osallisuus edellyttää saavutettavuutta (access). Manifestissa puhutaan jopa saavutettavuuden pedagogiikasta (pedagogy of access) pääsynä symboliseen pääomaan eli kaikkien oppilaiden yhdenvertaisena mahdollisuutena päästä käsiksi teksteihin, jotka ovat välttämättömiä sosiaalisen pääoman kasvattamiselle. Oppilaan on siksi kyettävä lukemaan menestyksen keskiössä olevia tekstejä, kuten oppikirjojen kaltaisia akateemisia tekstejä, joiden hallinta takaa osallisuuden yhteiskunnassa. Akateemisten tekstien hallinta ei kuitenkaan ollut itsestään selvää muun muassa alkuperäisväestöille ja maahanmuuttajille. Opetussuunnitelmat korostivat valtaväestön tekstejä ja opettajat portinvartioina valikoivat, mitä tekstejä oppilaat lukivat, miten ja milloin, mitä kaikkea lukemisen alueeseen sisältyi ja mitä teksteillä voitiin tehdä. 
Samalla saavutettavuus tarkoittaa valtavirrasta poikkeavien tekstien ottamista mukaan kouluopetukseen: se tavoittelee sekä marginaalisia kokemuksia ja elämismaailmoja että valtavirran avaintekstejä ja teknologioita. Näin avataan tietä oppilaan oman yhteiskunnallisen tulevaisuuden muotoiluun.

NLG piti koulua paikkana, jossa on mahdollista tukea erilaisia sosiaalisia suhteita ja identiteettejä, jotka voivat sisältää vaihtoehtoisia tulevaisuudennäkymiä. Siten koulu oli mahdollisuus yhteiskunnallisen tulevaisuuden muotoiluun ja maailman muuttamiseen (Serafini \& Gee 2017). Tässä NLG seuraa brasilialaista pedagogia Paulo Freireä, jota lainaten Luke toteaa, että "lukutaitojen on kosketeltava maailman lukemista ja kirjoittamista" (Garcia, Luke \& Seglem 2018, 74).

Optimismi yhteiskunnan muuttumisesta uusien mediateknologioiden avulla on kokenut kovia vuosituhannen toisella vuosikymmenellä, kun dis- ja misinformaatio, vihapuhe ja teknologiajättien valta ovat lisääntyneet verkossa. Luke viittaa "dystooppiseen mediaspektaakkeliin", joka on merkinnyt monien
NLG:n tavoitteiden luhistumista: "Digitaalisen etiikan, monilukutaitojen ja kansalaisuuden pitäisi olla kaikille opetussuunnitelman ytimessä" (Garcia, Luke \& Seglem 2018, 77).

NLG-ryhmästä muun muassa Mary Kalantzis ja Bill Cope jatkavat työtään aktiivisesti. Tuoreimman, vuonna 2020 ilmestyneen Adding Sense -kirjansa (2020) he linjaavat samaan jatkumoon. "Viikon lopulla [New Londonissa] keskustelu oli vedetty yhteen termillä 'monilukutaidot'. Sitten tuli artikkeli Harvard Educational Reviewissä, kirja, paljon muuta, ja nyt tämä.”

Monilukutaidon pedagogiikalla on vielä tehtävää.

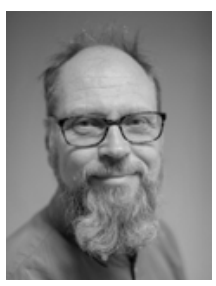

\section{REIJO KUPIAINEN}

FT, mediakasvatuksen yliopistonlehtori kasvatustieteiden ja kulttuurin tiedekunta Tampereen yliopisto

(D) https://orcid.org/0000-00032610-2294

\section{LÄHTEET.}

Cope, B. \& Kalantzis, M. (2000). Multiliteracies. Literacy Learning and the Design of Social Futures. London: Routledge.

Cope, B. \& Kalantzis, M. (2009). "Multiliteracies": New Literacies, New Learning. Pedagogies: An International Journal (4)3. https://doi.org/10.1080/ 15544800903076044

Garcia, A., Luke, A. \& Seglem, R. (2018). Looking at the next 20. Years of Multiliteracies: A Discussion with Allan Luke. Theory into Practice (57)1, 72-78. https:// doi.org/10.1080/00405841.2017.1390330

Gee, J. P. (2017). A Personal Retrospective on the New London Group and Its Formation. Teoksessa F. Serafini \& E. Gee (toim.) Remixing Multiliteracies. Theory and Practice from New London to New Times. New York: Teachers College Press, 19-34.

Kalantzis, M. \& Cope, B. (2020). Adding Sense: Context and Interest in a Grammar of Multimodal Meaning. Cambridge: Cambridge University Press.
Kress, G. (2003). Literacy in the New Media Age. London: Routledge.

Kupiainen, R. (2005). Mediakasvatuksen eetos. Fenomenologinen tutkimus mediakasvatuksen etiikasta. Acta Universitatis Lapponiensis 86. Rovaniemi: Lapin yliopisto.

Kupiainen, R. (2006). Yhteistoiminnallinen lukutaito. Aikuiskasvatus 26(3), 182-187. https://doi.org/ 10.33336/aik.93693

Kupiainen, R. (2013). Media and Digital Literacies in Secondary School. New York: Peter Lang

NLG, The New London Group (1996). A Pedagogy of Multiliteracies: Designing Social Futures. Harvard Educational Review 66(1), 60-92. https://doi.org/ 10.17763/haer.66.1.17370n67v22j160u

Serafini, F. \& Gee, E. (2017). Introduction. Teoksessa F. Serafini ja E. Gee (toim.) Remixing Multiliteracies: Theory and Practice from New London to New Times. New York: Teachers College Press, 1-16.

Klassikon paluu -sarjassa esitellään teoksia, jotka ovat olleet merkityksellisiä aikuiskasvatuksen tutkijoille ja ammattilaisille opinnoissa, tutkimuksessa ja työssä. 